\title{
PHYTOCHEMICAL AND PHARMACOLOGICAL EVALUATION OF CALLISTEMON CITRINUS FOR ANTIDEPRESSANT ACTIVITY IN ALBINO MICE
}

\author{
VIJETHA PENDYALA ${ }^{1}$, SANTHRANI THAAKUR ${ }^{2 *}$
}

\begin{abstract}
${ }^{1}$ Department of Pharmacognosy, Chebrolu Hanumaiah Institute of Pharmaceutical Sciences, Guntur, Andhra Pradesh, India. ${ }^{2}$ Departmet of Pharmacology, Institute of Pharmaceutical Technology, Sri Padmavathi Mahila Viswavidyalayam, Tirupati, Andhra Pradesh, India. Email: drsanthrani@gmail.com

Received: 07 April 2017, Revised and Accepted: 05 May 2017
\end{abstract}

ABSTRACT

Objective: The present study was carried out to find out the antidepressant activity of different fractions of stems and leaves of Callistemon citrinus (CC). The efficacy of the fractions was compared with the standard reference drug imipramine.

Methods: All the studies were conducted according to the ethical guidelines of CPCSEA. Healthy adult albino mice weighing 20-30 g were used as experimental animals. The leaves of CC were extracted with alcohol and fractionated with chloroform and petroleum ether. All the fractions were subjected for preliminary phytochemical screening, using various qualitative tests. In the present investigation, tail suspension test (TST) and forced swim test (FST) are selected as animal models for evaluation of antidepressant activity in albino mice.

Results: The preliminary phytochemical screening of CC has revealed the presence of carbohydrates, tannins, and flavonoids in a hydroalcoholic fraction. Chloroform fraction showed positive results toward flavonoids, alkaloids, tannins, glycosides, and steroids. Alcoholic and chloroform extract (100 and $200 \mathrm{mg} / \mathrm{kg}$ p.o.) of CC administered orally for 14 successive days had decreased the immobility periods significantly in a dose-dependent manner in both TST and FST, showing significant antidepressant-like activity. The activities of the extracts were found to be comparable to imipramine in both FST and TST.

Conclusions: Although a number of synthetic drugs are being used as a standard treatment for clinically depressed patient, they have adverse effects that can compromise the therapeutic treatment. In the traditional systems of medicine, many plants and formulations have been used to treat depression for thousands of years. The results of the study indicate that CC can be used as an antidepressant herb.

Keywords: Callistemon citrinus, Antidepressant activity, Forced swim test, Tail suspension test, Depression.

(c) 2017 The Authors. Published by Innovare Academic Sciences Pvt Ltd. This is an open access article under the CC BY license (http://creativecommons. org/licenses/by/4. 0/) DOI: http://dx.doi.org/10.22159/ajpcr.2017.v10i8.18998

\section{INTRODUCTION}

Depression is a psychiatric disorder, which affects $21 \%$ of the world population and is considered as disorders of mood rather than disturbances of thought or cognition. It is a chronic illness associated with low mood and a range of associated emotional, cognitive, physical, and behavioral symptoms [1]. There are two types of depression; the first one is unipolar depression, in which the mood swings are always in the same direction and caused due to stressful events of life. The second one is bipolar depression, also termed as endogenous depression, in which the mood swings are bidirectional and unrelated to external stress [2]. Although there are numerous synthetic drugs available for the treatment of depression, they are associated with various adverse effects and drug-drug interactions that can compromise the treatment [3]. Therefore, this aim was to search for antidepressants from plants and explore their potential in the treatment of depression.

The genus Callistemon is known for its anti-cough, anti-bronchitis, and insecticidal properties. Callistemon citrinus (CC) (Family: Myrtaceae) commonly known as bottlebrush tree grows in Australia and cultivated throughout India, Malaysia, and tropical countries. CC has been claimed in traditional literature to be valuable against a wide variety of diseases $[4,5]$. The plant has been used by tribal communities for the treatment of gastrointestinal disorders, and the leaves are used for their anthelmintic, anti-inflammatory, antipyretic, and antitussive properties.

The phytoconstituents reported from CC are flavonoids: Pelargonidin3,5-diglucoside, cyanidin-3,5-diglucoside, and kaempferol; monoterpenoids: $\beta$-pinene and 1,8-cineole; tannins: Pyrogallol and catechol; triterpenoids: Betulinic acid, $\alpha$-amyrin and oleanolic acid, and $\beta$-sitosterol in flowers and fruits $[6,7]$. The leaves contain flavonoids: $3^{\prime} 4^{\prime} 7$-trihydroxy flavonol, $3^{\prime} 4^{\prime} 7$-trihydroxy flavone, 3'4'7-trihydroxy flavonol-3-glucoside, 3'4'7-trihydroxy flavone-7galactoside, 5,7-dihydroxy-3,8,4'-trimethoxy-6-C-methylflavone, kaempferol-3-0- $\beta$-D-galactopyranoside, and quercetin-3-0-(2"0 -galloyl)- $\beta$-D-glucopyranoside $[8,9]$. The leaves are reported to contain monoterpenoids: 1,8-cineole, $\alpha$-pinene, and limonene and triterpenoids: $\alpha$-lupeol, $2 \alpha$-hydroxy uvaol, $2 \alpha$-hydroxy ursolic acid, ursolic acid, oleanolic acid, and phloroglucinol derivative $[10,11]$.

The pharmacological activities reported for CC are antiasthmatic, antimicrobial, calcium channel blocker, cytotoxicity, and anthelmintic effects [12]. The literature review reveals that no study was done on the antidepressant property of this plant scientifically. Therefore, this study focused on evaluation of antidepressant potential of CC in mice.

\section{MATERIALS AND METHODS}

\section{Collection of plant material and extraction}

The aerial parts of CC were collected at NH-5 near Guntur. The plant was authentified by the Department of Botany, Acharya Nagarjuna University, Guntur, and voucher specimen was preserved. The leaves and stems were separated, dried, powdered, and then extracted with alcohol as solvent using soxhelation for 4 cycles. Then, the extracted drug was further evaporated using simple distillation apparatus to obtain the concentrate. To this extract, aliquots of water were added and then fractionated successively using petroleum ether and chloroform 
by mother liquor method [13]. To this extract, $250 \mathrm{ml}$ of water was added and shaken thoroughly, and then to this, $100 \mathrm{ml}$ of petroleum ether was added to separate the non-polar constituents. This procedure was repeated until the appearance of colorless petroleum ether layer. All the fractions of petroleum ether layer were collected and evaporated to a concentrated residue. After separation of petroleum ether fraction, $100 \mathrm{ml}$ of chloroform was added to the hydroalcoholic extract and this procedure is repeated until the chloroform layer becomes colorless. All the fractions of chloroform layer were collected and evaporated to a concentrated residue. The leftover portion is considered as hydroalcoholic fraction.

\section{Preliminary phytochemical screening}

Various qualitative tests were performed for the detection of phytochemical constituents present in all three fractions, for the presence of carbohydrates, tannins, flavonoids, steroids, glycosides, alkaloids, and saponins [14].

\section{Animals}

Swiss albino mice of either sex 3-4 months old and weighing around 20-30 g were selected. The animals had free access to food and water and were housed in an animal room with alternating light-dark cycle of $12 \mathrm{hrs}$ each. The animals were acclimatized for at least 5 days to the laboratory conditions before the commencement of behavioral experiments. Experiments were carried out between 9:00 am and 11:00 am. The Institutional Animal Ethics Committee (IAEC) approved the experimental protocol, and the care of laboratory animals was taken as per the guidelines of CPCSEA, Ministry of Forests and Environment, Government of India (1529/PO/A/11/CPCSEA/IAEC3/ PRO-03/2015-2016).

\section{Preparation of standard}

Imipramine was procured from Baroda Pharmaceuticals as a gift sample. Stock solution was prepared by dissolving $10 \mathrm{mg}$ in $10 \mathrm{ml}$ of distilled water, and then diluted to required dilutions.

\section{Measurement of antidepressant activity in albino mice}

In the present investigation, tail suspension test (TST) and forced swim test (FST) were selected as animal models for the evaluation of antidepressant activity in albino mice.

\section{Experimental protocol}

Animals were divided into 16 groups, and each group consists of 6 mice.

\section{TST}

The total duration of immobility induced by tail suspension was measured according to the method described by steru [15] and Thierry [16]. Mice were suspended on the edge of a table $50 \mathrm{~cm}$ above the floor by the adhesive tape placed approximately $1 \mathrm{~cm}$ from the tip of the tail. Immobility time was recorded during a 6-minute period. Animal was considered to be immobile when it did not show any movement of the body and hanged passively. Each animal was used only once. The experimental protocol and treatment schedule were given in Table 1.

\section{FST}

FST was proposed as a model for antidepressant activity by Porsolt et al. $[17,18]$. Mice were forced to swim individually in a glass jar containing fresh water of $15 \mathrm{~cm}$ height and maintained at $25^{\circ} \mathrm{C}\left( \pm 3^{\circ} \mathrm{C}\right)$. Mice were considered to be immobile when it remained floating in the water without struggling, making no or minimum movements of its limbs necessary to keep its head above water. The total duration of immobility was recorded during a 6-minute test. The changes in immobility duration were studied in all groups of animals. The experimental protocol and treatment schedule were similar to TST. On the $14^{\text {th }}$ day, 90 minutes after administration of extracts, immobility period was recorded in all groups.
Statistical analysis

All the results were expressed as mean \pm standard error. Data were analyzed using one-way ANOVA followed by Dunnett's test. In all the tests, the criterion for statistical significance was $\mathrm{p}<0.05$.

\section{RESULTS AND DISCUSSION}

Depression is a psychiatric disorder that affects individuals' quality of life, emotional and social relations directly. Most of the therapies require several weeks of treatment; there are various side effects caused by conventional antidepressant drugs before improvement of signs and symptoms is observed. To overcome these limitations of available antidepressant drugs, attempts are underway to explore medicinal plants with antidepressant activity. Many single and compound drug formulations of plant origin are being used in the treatment of psychiatric disorders and proved to have a better acceptance due to lower incidence of side effects $[19,20]$. Nowadays, plants with chemical constituents such as flavonoids, phenols, alkaloids, and triterpenoid saponins were reported to have antidepressant activity. Preliminary phytochemical screening was done for petroleum ether, chloroform, and alcoholic fractions of CC using various qualitative tests. The results of phytochemical screening are presented in Tables 2 and 3.

Table 1: Experimental protocol for TST and FST

\begin{tabular}{ll}
\hline Group & Treatment schedule for TST \\
\hline Control & $\begin{array}{l}\text { Only distilled water was administered orally for } \\
\text { 14 days } \\
\text { Imipramine }(10 \mathrm{mg} / \mathrm{kg}) \text { was administered orally for }\end{array}$ \\
Standard & 14 days \\
CCA1 & CCA $(100 \mathrm{mg} / \mathrm{kg})$ was administered orally for 14 days \\
CCA2 & CCA $(200 \mathrm{mg} / \mathrm{kg})$ was administered orally for 14 days \\
CCC1 & CCC $(100 \mathrm{mg} / \mathrm{kg})$ was administered orally for 14 days \\
CCC2 & CCC $(200 \mathrm{mg} / \mathrm{kg})$ was administered orally for 14 days \\
CCP1 & PCC $(100 \mathrm{mg} / \mathrm{kg})$ was administered orally for 14 days \\
CCP2 & PCC $(200 \mathrm{mg} / \mathrm{kg})$ was administered orally for 14 days
\end{tabular}

Groups 9-16 were similar to 1-8, except, that the immobility time was recorded using FST. FST: Forced swim test, TST: Tail suspension test, CC: Callistemon citrinus, CCA: Callistemon citrinus with alcoholic, CCC: Callistemon citrinus with chloroform, CCP: Callistemon citrinus with petroleum ether

Table 2: Percentage yield of different fractions of CC extract

\begin{tabular}{ll}
\hline Fraction & \% Yield \\
\hline Petroleum ether (CCP) & 0.9 \\
Chloroform (CCC) & 6.5 \\
Alcohol (CCA) & 7.0 \\
\hline
\end{tabular}

CC: Callistemon citrinus, CCA: Callistemon citrinus with alcoholic, CCC: Callistemon citrinus with chloroform, CCP: Callistemon citrinus with petroleum ether

Table 3: Preliminary phytochemical analysis of fractions of CC extract

\begin{tabular}{llll}
\hline Phytochemical & CCP & CCC & CCA \\
\hline Alkaloids & -ve & +ve & -ve \\
Glycosides & $-\mathrm{ve}$ & $+\mathrm{ve}$ & $+\mathrm{ve}$ \\
Flavonoids & $-\mathrm{ve}$ & $+\mathrm{ve}$ & $+\mathrm{ve}$ \\
Carbohydrates & $-\mathrm{ve}$ & $-\mathrm{ve}$ & $+\mathrm{ve}$ \\
Tannins & $-\mathrm{ve}$ & $+\mathrm{ve}$ & $+\mathrm{ve}$ \\
Steroids & $+\mathrm{ve}$ & $+\mathrm{ve}$ & $-\mathrm{ve}$ \\
Fats and oils & $+\mathrm{ve}$ & $-\mathrm{ve}$ & $-\mathrm{ve}$ \\
\hline
\end{tabular}

CC: Callistemon citrinus, CCA: Callistemon citrinus with alcoholic, CCC: Callistemon citrinus with chloroform, CCP: Callistemon citrinus with petroleum ether 
Table 4: Effect of CC on immobility time in FST

\begin{tabular}{lll}
\hline Groups & $\begin{array}{l}\text { Mean } \pm \text { SEM of immobility } \\
\text { time (seconds) }\end{array}$ & $\begin{array}{l}\text { \% Decrease in } \\
\text { immobility time }\end{array}$ \\
\hline Control & $97.6 \pm 5.2$ & \\
Standard & $22.5 \pm 2.17^{* *}$ & 77 \\
CCA $100 \mathrm{mg} / \mathrm{kg}$ & $38.5 \pm 4.82^{*}$ & 60.5 \\
CCA $200 \mathrm{mg} / \mathrm{kg}$ & $26.5 \pm 3.14^{* *}$ & 72.9 \\
CCC $100 \mathrm{mg} / \mathrm{kg}$ & $31.6 \pm 2.30^{*}$ & 67.7 \\
CCC $200 \mathrm{mg} / \mathrm{kg}$ & $23.2 \pm 2.51^{* *}$ & 76.3 \\
CCP $100 \mathrm{mg} / \mathrm{kg}$ & $78.5 \pm 5.02$ & 20 \\
CCP $200 \mathrm{mg} / \mathrm{kg}$ & $40.6 \pm 4.24^{*}$ & 49.5 \\
\hline
\end{tabular}

Values are expressed as mean \pm SEM, ${ }^{*} \mathrm{p}<0.05,{ }^{* *} \mathrm{p}<0.01$ versus control group. CC: Callistemon citrinus, CCA: Callistemon citrinus with alcoholic, CCC: Callistemon citrinus with chloroform, CCP: Callistemon citrinus with petroleum ether, SEM: Standard error of mean, FST: Forced swim test

Table 5: Effect of CC on immobility time in TST

\begin{tabular}{lll}
\hline Groups & $\begin{array}{l}\text { Mean } \pm \text { SEM of immobility } \\
\text { time (seconds) }\end{array}$ & $\begin{array}{l}\text { \% Decrease in } \\
\text { immobility time }\end{array}$ \\
\hline Control & $184.3 \pm 8.01$ & \\
Standard & $69.2 \pm 5.71^{* *}$ & 73.4 \\
CCA $100 \mathrm{mg} / \mathrm{kg}$ & $114 \pm 4.70^{*}$ & 38 \\
CCA $200 \mathrm{mg} / \mathrm{kg}$ & $85.3 \pm 5.12^{* *}$ & 54 \\
CCC $100 \mathrm{mg} / \mathrm{kg}$ & $111.6 \pm 5.77^{*}$ & 40 \\
CCC $200 \mathrm{mg} / \mathrm{kg}$ & $78.5 \pm 4.18^{* *}$ & 57.5 \\
CCP $100 \mathrm{mg} / \mathrm{kg}$ & $165.2 \pm 6.21$ & 11 \\
CCP $200 \mathrm{mg} / \mathrm{kg}$ & $121.2 \pm 5.21^{*}$ & 34 \\
\hline
\end{tabular}

Values are expressed as mean \pm standard error of mean (SEM), ${ }^{*} \mathrm{p}<0.05,{ }^{* *} \mathrm{p}<0.01$ versus control group. CC: Callistemon citrinus, CCA: Callistemon citrinus with alcoholic, CCC: Callistemon citrinus with chloroform, CCP: Callistemon citrinus with petroleum ether. TST: Tail suspension test

In this study, we used the animal models TST and FST, which are widely accepted behavioral models for assessing antidepressant activity. Reduction in immobility time is the characteristic behavior scored in these tests, reflecting behavioral despair as seen in human depression. In addition, it is well known that conventional antidepressant drugs are able to reduce the immobility time in rodents [21]. This decrease in duration of immobility is considered to have a good predictive value in the evaluation of potential antidepressant agents. The results of different extracts of CC on the immobility duration in TST are presented in Table 4. Administration of CC alcoholic (CCA), CC chloroform (CCC), and CC petroleum ether (CCP) fractions of CC $200 \mathrm{mg} / \mathrm{kg}$ for 14 successive days decreased the immobility time in TST by $54 \%, 57.5 \%$, and $34 \%$, respectively, as compared to control group. CCA, CCC, and CCP $200 \mathrm{mg} / \mathrm{kg}$ administration for 14 days decreased immobility time in FST by $72.9 \%$, $76.3 \%$, and $49.5 \%$, respectively, as compared to control group. Standard drug imipramine $10 \mathrm{mg} / \mathrm{kg}$ on 14 days treatment decreased the immobility time by $73.4 \%$ and $77 \%$, respectively, in TST and FST as compared to control group (Tables 4 and 5). A dose of $200 \mathrm{mg} / \mathrm{kg}$ p.o. CCC extract showed a potent antidepressant-like effect in both TST and FST as indicated by highest decrease in immobility period. The effect was comparable to a standard drug in FST.

\section{CONCLUSION}

In the present study, the preliminary phytochemical analysis revealed that the presence of tannins and flavonoids in hydroalcoholic fraction. Chloroform fraction showed positive results toward flavonoids, alkaloids, and steroids. Petroleum ether fraction showed positive results toward sterols and lipids; CCA and CCC showed a significant decrease in immobility time in both FST and TST indicating their antidepressant activity.

Chloroform fraction of CC showed antidepressant activity, which was comparable to a standard drug, i.e., imipramine $(10 \mathrm{mg} / \mathrm{kg})$. As reported earlier, CC contains many bioactive compounds and majority of these compounds are terpenoids and flavonoids that are responsible for the health benefits. Therefore, this study explores the use of CC in the treatment of depression. Further study can be explored to isolate the active constituents and evaluate the mechanism of antidepressant activity of CC.

\section{ACKNOWLEDGMENTS}

The authors are grateful to the management of Chebrolu Hanumaiah Institute of Pharmaceutical Sciences and Sri Padmavathi Mahila Viswa Vidyalayam for extending their support and providing facilities to complete this work

\section{REFERENCES}

1. Rang HP, Dale MM, Ritter JM. Pharmacology. $6^{\text {th }}$ ed. Edinburgh: Churchill Livingstone; 2007. p. 553.

2. Dhingra D, Sharma A. A review on antidepressant plants. Nat Prod Radiance 2005;5(2):144-52.

3. Tripathi KD. Essentials of Medical Pharmacology. $6^{\text {th }}$ ed. New Delhi: Medical Publishers; 2008. p. 425

4. Chopra RN, Nayar SI, Chopra IC. Glossary of Indian Medicinal Plants. New Delhi: CSIR; 1956. p. 128.

5. Sastri BN. The Wealth of India, Raw Materials and Industrial Products. New Delhi: CSIR-NISCAIR; 1956. p. 266.

6. Mishra LN, Hug F, Ahmad A, Dixit AK. Chemical composition of the essential oils of Callistemon lanceolatus DC and Callistemon polandii FM. Bailey J Essent Oil Res 1997;9(6):625

7. Hashim FM, Shamy AM, Shehata AH. The flavonoids of the leaves of Callistemon lanceolatus DC. And Callistemon rigidus R. Br Bull Fac Pharm 1982;19(1):139.

8. Jirovetz L, Fleischacker W, Buchbauer G, Ngassoum MB. Analysis of the essential oils of Callistemon rigidus (Myrtaceae) from Cameroun by GC/FID and GC/MS. Sci Pharm 1997;65:315.

9. Ming JC, Verra RR, Fraisso DJ. Chemical composition of essential oil of Callistemon citrinus (Curtis) skeel. Reunion J Essent Oil Res 1998; 10:429.

10. Sharma RK, Kotoky R, Bhattacharya PR. Volatile oil from the leaves of Callistemon lanceolatus grown in Northeastern India. Flavour Fragr $\mathrm{J}$ 2006;21(2):239.

11. Lounasmaa M, Puri HS, Widen CJ. A new dioleate compound from Callistemon lanceolatus. Phytochemistry 1977;16(11):1851

12. Mohmoud FA, Mohrram MS, Marzouk MW, Salen MI. Polyphenolic constituents of Callistemon lanceolatus leaves. Pharmazie 2002;57(7):494.

13. Harborne JB. Phytochemical Methods: A Guide to Modern Techniques of Plant Analysis. $2^{\text {nd }}$ ed. New York: Chapman and Hall; 1984. p. 1-10.

14. Kokate CK, Purohit AP, Gokhale SB. Pharmacognosy. $12^{\text {th }}$ ed. Pune: Nirali Publications; 1999. p. 157-9.

15. Steru L, Chermat R, Thierry B, Simon P. The tail suspension test: A new method for screening antidepressants in mice. Psychopharmacology (Berl) 1985;85(3):367-70.

16. Thierry B, Stéru L, Simon P, Porsolt RD. The tail suspension test: Ethical considerations. Psychopharmacology (Berl) 1986;90(2):284-5

17. Porsolt RD, Bertin A, Jalfre M. Behavioral despair in mice: A primary screening test for antidepressants. Arch Int Pharmacodyn Ther 1977;229(2):327-36

18. Porsolt RD, Castagne V, Moser P. Behavioral assessment of antidepressant activity in rodents. In: Buccafusco JJ, editor. Methods of Behavior Analysis in Neuroscience. $2^{\text {nd }}$ ed. Ch. 6. Boca Raton, (FL): CRC Press; 2009. Available from: http://www.ncbi.nlm.nih.gov/books/ NBK5222.

19. Santhosh P, Venugopal R, Nilakash S, Kunjbihari S, Mangala L. Anti depressant activity of methanolic extract of Passiflora foetida leaves in mice. Int J Pharm Pharm Sci 2011;3(1):112-5.

20. Umadevi P, Murugan S, Jennifer S, Subakanmani S. Evaluation of antidepressant like activity of Cucurbita pepo seed extracts in rats. Int $\mathrm{J}$ Curr Pharm Res 2010;3(1):108-13.

21. Sutar RC, Kasture SB, Kalaichelvan VK. Evaluation of antidepressant activity of leaf extracts of Holoptelea integrifolia (Roxb) planch in experimental animals. Int J Pharm Pharm Sci 2014;6(6):250-3. 